\title{
Evaluation of thecytotoxic activity of extracts from medicinal plants used for the treatment of malaria in Kagera and Lindi regions, Tanzania
}

\author{
Ramadhani S. O. Nondo ${ }^{1 *}$, Mainen J. Moshi ${ }^{1}$, Paul Erasto ${ }^{2}$, Denis Zofou ${ }^{3,4}$, Abdel J. Njouendou ${ }^{4}$, Samuel Wanji ${ }^{4}$, Moses \\ N. Ngemenya ${ }^{3}$, Abdul W Kidukuli ${ }^{1}$, Pax J. Masimba ${ }^{1}$, Vincent P.K. Titanji ${ }^{3}$ \\ ${ }^{1}$ Department of Biological and Pre-Clinical Studies, Institute of Traditional Medicine, Muhimbili University of Health and Allied Sciences, Dar es Salaam, \\ Tanzania. ${ }^{2}$ National Institute for Medical Research, Dar es Salaam, Tanzania. ${ }^{3}$ Biotechnology Unit, University of Buea, Buea, South West Region, \\ Cameroon. ${ }^{4}$ Research Foundation in Tropical Diseases and Environment, Buea, South West Region-Cameroon.
}

\section{ARTICLE INFO \\ Article history: \\ Received on: 06/02/2015 \\ Revised on: 18/02/2015 \\ Accepted on: 09/03/2015 \\ Available online: 27/04/2015}

Key words:

Toxicity, medicinal plants,

malaria, LLC-MK2 cells,

brine shrimps assay,

Tanzania

\begin{abstract}
A number of medicinal plants used for treatment of malaria in Tanzania have been documented, but information on their safety and efficacy is still based on traditional knowledge accumulated over years and not on pre-clinical and clinical evaluation. The present study aimed to assess the cytotoxic activity of extracts of selected plant species used for treatment of malaria in Tanzania. Ethanol extracts were evaluated for cytoxicity by using MTT assay on LLC-MK2 cells and by brine shrimp lethality assay. Forty five (93.75\%) out of 48 crude extracts assessed using LLC-MK2 cells were non-cytotoxic while three extracts $(6.25 \%)$ were cytotoxic with $\mathrm{CC}_{50}<30$ $\mu \mathrm{g} / \mathrm{mL}$ (cut-off point). In the brine shrimp assay $30(65.2 \%)$ out of 46 extracts tested were non-toxic while 16 extracts $(34.8 \%)$ were toxic $\left(\mathrm{LC}_{50}<100 \mu \mathrm{g} / \mathrm{mL}\right)$. Antiaris toxicaria stem bark extract was the most cytotoxic to mammalian cells. This study demonstrates that, most of the antimalarial plants tested were non-toxic. These observations corroborate with traditional healers' claims that the herbal medicines used in their areas are safe. However, further studies using different toxicity models are suggested to further confirm their claims.
\end{abstract}

\section{INTRODUCTION}

The use of plants as source of medicines for treatment of infectious and non-infectious diseases is an old human tradition (Petrovska, 2012), and the practice is now increasing due to increased global health challenges (WHO, 2002). Malaria is one of diseases treated by herbal medicines originating from different plant parts such as roots, stem bark, leaves, flowers and fruits. It is an old life threatening parasitic disease caused by parasites of the genus Plasmodium. The parasites infect and destroy red blood cells, leading to fever, severe anaemia, cerebral malaria and death may occur if the patient is not treated properly and on time (Fidock et al., 2004; NIAID, 2007).

\footnotetext{
* Corresponding Author

Ramadhani SO Nondo, Department of Biological and Pre-Clinical Studies, Institute of Traditional Medicine, Muhimbili University of Health and Allied Sciences, Dar es Salaam, Tanzania.

Email:nondo75@yahoo.com
}

Exploration of the accumulated indigenous knowledge on the treatment of malaria using medicinal plants enabled the isolation of two important and currently used antimalarial drugs; artemisinin from Artemisia annua and quinine from the bark of Cinchona spp (Wells, 2011). Despite plants being a rich source of useful chemical compounds of various structures and with different pharmacological properties on biological systems (Butler, 2004; Moshi et al., 2009), some of them may be toxic to humans. For example, some of the toxicities associated with the use of medicinal plants include allergic reactions, irritation of the gastrointestinal tract, destruction of red blood cells, and damage of body organs such as the heart and kidney and carcinogenicity (Westendorf, 1999; IARC, 2012). Several medicinal plants have previously been reported to be toxic. Some of the examples include Symphytum officinale $L$. used for wound healing which contains hepatotoxic pyrrolizidine alkaloids and Valerian officinalis used as a sedative for treatment of insomnia and anxiety which causes hepatitis 
(Abdualmjid and Segi, 2013). Aristolochia spp contain aristolochic acid I and II that cause renal failure (Debelle et al., 2008); Drimia sanguinea and Bowiea volubilis which are traditionally used for headache, oedema, infertility and bladder problems contain cardiotoxic bufadienolides (Van der Bijl Jr. and Van der Bijl Sen., 2012). Although the use of herbal medicines is controlled in many countries, information about their efficacy and safety is based on traditional knowledge transmitted through generations over years and not on pre-clinical and clinical evaluation (Chalut et al., 1999). Tanzania shares the same experience of having a number of traditional healers who use traditional medicines for treatment of different diseases and is endowed with over 12,000 plant species, of which at least $10 \%$ have medicinal values (Mahunnah et al., 2012). Furthermore, Tanzania is among the six African countries with many reported cases of malaria (WHO, 2012) and because of the long history of the disease, the practice of using medicinal plants to treat malaria is very common (Mahunnah, 1987; Gessler et al., 1995 Kinung'hi et al., 2010). Although several antimalarial medicinal plants have been documented in Tanzania, their safety has not been well studied. Therefore in this study the toxicity of crude extracts of medicinal plants used for the treatment of malaria in Kagera and Lindi regions, Tanzania, were assessed using the LLC- MK2 monkey kidney epithelial cell line and the brine shrimp larvae (Artemia salina $\mathrm{L}$.).

\section{MATERIALS AND METHODS}

\section{Materials}

Monkey kidney epithelial cells, LLC-MK2 $\left(\mathrm{ATCC}^{\circledR}\right.$, USA) were obtained from American Type Culture Collections (USA) and ethanol (Carlo erba ${ }^{\circledR}$ ) was purchased from Techno Net Scientific (Dar es Salaam, Tanzania). Foetal Bovine Serum (FBS, BioWhittaker $^{\circledR}$, Verviers, Belgium), RPMI-1640 medium (Sigma), MTT 3-(4,5-dimethylthiazol-2-yl)-2,5-diphenyl tetrazolium bromide (Sigma), sodium bicarbonate (sigma), dimethylsulfoxide (Sigma), cell culture flasks (Corning, NY, USA), 96 well cell culture plates $\left(\right.$ Costar $^{\circledR}$, Corning, NY, USA), Centrifuge tubes (Corning, NY, USA), Syringe adapted filters $0.22 \mu \mathrm{m}$ (Corning, NY, USA), Trypsin-EDTA (Sigma) were all purchased from Sigma (Steinheim, Germany). Plant materials were collected from Kagera (November, 2012) and Lindi (July, 2012) regions, Tanzania. Identification of the plants was done by Mr. Haji. O. Selemani, a Botanist at the Department of Botany, University of Dar es Salaam, and the voucher specimens are deposited at the University of Dar es Salaam and at Muhimbili University of Health and Allied Sciences Herbaria, Tanzania.

\section{Extraction of crude extracts}

The powdered plant materials were macerated in $80 \%$ ethanol at room temperature for $24 \mathrm{~h}$ and then filtered through cotton wool. The solid plant materials were macerated again in the same solvent for another $24 \mathrm{~h}$ and the extracts obtained from the first and the second extractions were pooled and concentrated under vacuo using a Heldolph ${ }^{\circledR}$ rotary evaporator (Heldolph instruments $\mathrm{GmbH}$, Schwabach, Germany) to obtain viscous extracts which were further dried using a freeze drier (Edwards High Vacuum International, Crawley Sussex, England). The dry extracts were stored at $-20^{\circ} \mathrm{C}$ until use.

\section{Preparation of stock solutions}

Stock solutions were prepared by dissolving $4 \mathrm{mg}$ of crude extracts in $100 \mu \mathrm{L}$ dimethyl sulfoxide and then diluted with RPMI- 1640 cell culture medium to make $400 \mu \mathrm{g} / \mathrm{mL}$. All solutions were sterilized by passing through $0.22 \mu \mathrm{m}$ syringe-adapted filters and stored at $-20^{\circ} \mathrm{C}$ until use.

\section{Determination of cytotoxic activity on LLC-MK2 cells}

Cytotoxicity of the crude extracts was evaluated on LLCMK2 monkey kidney epithelial cells. Cells were grown in RPMI1640 culture medium with L-glutamine and $25 \mathrm{mM}$ HEPES (Steinheim, Germany). The medium was supplemented with 2 $\mathrm{mg} / \mathrm{mL} \mathrm{NaHCO}_{3}$ (sigma), $10 \mu \mathrm{g} / \mathrm{mL}$ hypoxanthine (Sigma), 11.1 $\mathrm{mM}$ glucose (sigma), 10\% FBS (BioWhittaker ${ }^{\circledR}$, Verviers, Belgium) and $5 \mu \mathrm{g} / \mathrm{mL}$ gentamicin. The cells were incubated at $5 \%$ $\mathrm{O}_{2}, 5 \% \mathrm{CO}_{2}$, and $90 \% \mathrm{~N}_{2}$ in humidified incubator (SHEL LAB ${ }^{\mathrm{TM}}$, Sheldon Mfg Inc, OR, USA) at $37^{\circ} \mathrm{C}$ until confluent before used for cytotoxicity assay. Trypsinated cells were distributed in 96 well plates at 10,000 cells in $100 \mu \mathrm{L}$ per well and incubated for 48 $\mathrm{h}$ to allow them to attach before adding the extract. After $48 \mathrm{~h}$ the medium was removed completely from each well, and $100 \mu \mathrm{L}$ of fresh culture medium was then added. Thereafter $100 \mu \mathrm{L}$ of crude extracts $(400 \mu \mathrm{g} / \mathrm{mL})$ were added in row $\mathrm{H}$ and then serially diluted to row B to give concentrations ranging from $200-3.125$ $\mu \mathrm{g} / \mathrm{mL}$. Cells in row A served as controls without drug $(100 \%$ growth). The cells with or without extracts were incubated at $37^{\circ} \mathrm{C}$ for $72 \mathrm{~h}$ before determining their viability. Each concentration level was tested in triplicate.

\section{MTT Assay}

Cell viability was determined using MTT assay (Niles et al., 2008; 2009). After $72 \mathrm{~h}$ of incubation, the culture medium in each well with or without extract was removed completely from the assay plates and replaced by $100 \mu \mathrm{L}$ of fresh culture medium. Then $10 \mu \mathrm{L}$ of $5 \mathrm{mg} / \mathrm{mL}$ Thiazolyl Blue Tetrazolium Bromide, MTT (Sigma) were added into each well to achieve a final concentration of $0.45 \mathrm{mg} / \mathrm{mL}$ before incubated for $3 \mathrm{~h}$ at $37^{\circ} \mathrm{C}$. After $3 \mathrm{~h}$, the culture medium with MTT was carefully removed followed by addition of $100 \mu \mathrm{L}$ dimethylsulfoxide to dissolve formazan crystals and then incubated for $1 \mathrm{~h}$ before recording the optical density (Emax-Molecular Devices Corporation, California, USA) at $595 \mathrm{~nm}$.

\section{Data analysis}

The percentage viability and percentage mortality were calculated from the OD values using Microsoft Excel 2010. The mean results of the percentage mortality were plotted against the logarithms of concentrations using the Fig $\mathrm{P}$ computer program Ver 4.189/07 (Biosoft Inc, USA). Regression equations obtained 
from the graphs were used to calculate the fifty percent cytotoxic concentration $\left(\mathrm{CC}_{50}\right)$, which is the concentration killing fifty percent of the cells. An extract with $\mathrm{CC}_{50}>30 \mu \mathrm{g} / \mathrm{mL}$ is considered non-toxic (Fadeyi et al., 2013).

\section{Brine shrimp toxicity assay}

The brine shrimp lethality assay is a non-specific toxicity assay that is used in natural products research to detect the presence of pharmacologically active chemical constituents. It uses Artemia salina L. (Artemiidae) larvae (Meyer et al., 1982). Solutions of plant extracts were made in dimethylsulfoxide. The brine shrimp toxicity assay was conducted and data analyzed as previously reported (Nondo et al., 2011). An $\mathrm{LC}_{50}$ (concentration killing fifty percent of the brine shrimp larvae) value greater than $100 \mu \mathrm{g} / \mathrm{mL}$ is considered to represent a non-toxic compound or extract (Moshi et al., 2010). Each extract was tested in duplicate and the concentrations of dimethylsulfoxide were restricted to a maximum of $0.6 \%$ in the final volume.

\section{RESULTS AND DISCUSSION}

Forty eight extracts from 38 medicinal plants distributed into 19 different plant families were evaluated for cytotoxic activity on mammalian cells (LLC-MK2 cells) as presented in Table 1. The results revealed that $45(93.75 \%)$ out of 48 extracts tested were non-cytotoxic and exhibited $\mathrm{CC}_{50}$ values above the cut-off point which is $30 \mu \mathrm{g} / \mathrm{mL}$. Of these, 33 extracts $(73.3 \%)$ from 24 plant species were found to have $\mathrm{CC}_{50}$ values above 200 $\mu \mathrm{g} / \mathrm{mL}$, the highest concentration tested. Only three $(6.25 \%)$ out 48 extracts were found to be cytotoxic with $\mathrm{CC}_{50}<30 \mu \mathrm{g} / \mathrm{mL}$ (cut-off point). The extracts were from Aspilia natalensis aerial parts $(18.57 \pm 1.04 \mu \mathrm{g} / \mathrm{mL})$, Antiaris toxicaria leaves $(12.51 \pm 0.65$ $\mu \mathrm{g} / \mathrm{mL})$ and Antiaris toxicaria stem bark $(1.44 \pm 0.48 \mu \mathrm{g} / \mathrm{mL})$ (Table 1).

The brine shrimp toxicity assay showed that thirty extracts $(65.2 \%)$ out of the 46 extracts tested had $\mathrm{LC}_{50}$ values greater than $100 \mu \mathrm{g} / \mathrm{mL}$; the cut-off point. Among these, 8 extracts had $\mathrm{LC}_{50}$ values greater than $1000 \mu \mathrm{g} / \mathrm{mL}$, while the remaining had $\mathrm{LC}_{50}$ values between 100 and $800 \mu \mathrm{g} / \mathrm{mL}$. Only Sixteen extracts (34.8\%) showed $\mathrm{LC}_{50}<100 \mu \mathrm{g} / \mathrm{mL}$, and therefore classified as toxic. Maesa lanceolata leaf extract was the most toxic with $\mathrm{LC}_{50}$ $=1.55 \mu \mathrm{g} / \mathrm{mL}$, followed by the extracts from Dalbergia malangensis leaves $(16.47 \mu \mathrm{g} / \mathrm{mL})$, Aspilia natalensis aerial parts (34.93 $\mu \mathrm{g} / \mathrm{mL})$, Desmodium salicifolium stem $(36.87 \mu \mathrm{g} / \mathrm{mL})$, and Dalbergia malangensis stem extract $(47.59 \mu \mathrm{g} / \mathrm{mL})$ (Table 2). The high toxicity of $M$. lanceolata leaf extract on brine shrimp larvae may be due to the effect of saponins. Previous studies revealed that the leaves of $M$. lanceolata are rich in triterpenoidal saponins and these compounds were reported to have high molluscicidal and hemolytic activities (Sindambiwe et al., 1998; Apers et al., 2001). According to the American National Cancer Institute (NCI), a crude plant extract is considered to be cytotoxic if its $\mathrm{CC}_{50}$ value on mammalian cells is $<30 \mu \mathrm{g} / \mathrm{mL}$ (Fadeyi et al., 2013). On the other hand the cut-off point to consider a crude plant extract non- toxic in the brine shrimp toxicity assay is $\mathrm{LC}_{50}>100 \mu \mathrm{g} / \mathrm{mL}$ (Moshi et al., 2010). Based on the results obtained in the two bioassays, three extracts were found to be toxic against LLC-MK2 cells and 16 extracts were found to be toxic on brine shrimp larvae. Of these only one extract from A. natalensis aerial parts was found to be toxic in both assays, which may be an indicator of consensus for cytotoxicity.

The extract from A. toxicaria stem bark was ranked the most toxic on the mammalian cells (LLC-MK2 cells) but it was ranked as exceptionally non-toxic using the brine shrimp toxicity assay (with $\mathrm{LC}_{50}>1,000 \mu \mathrm{g} / \mathrm{mL}$ ). On the other hand $M$. lanceolata leaf extract was ranked as the most toxic on brine shrimp assay with $\mathrm{LC}_{50}=1.55 \mu \mathrm{g} / \mathrm{mL}$ but ranked as non-toxic on LLC-MK2 cells test (Table 1 and 2). These observations suggest that the two models used in this study complement each other for the detection of toxic compounds that may be attributed to different mechanisms of toxicity; although the brine shrimp bioassay was found to be more sensitive in detecting toxic extracts than LLC-MK2 cells. The difference may be explained partly by the non-specificity of the brine shrimp assay in detecting toxic compounds (Meyer et al., 1982) and the differences in the criteria set to define a toxic substance, although in some studies brine shrimp assay has been reported to demonstrate some correlation with cell line results for detecting cytotoxic compounds/extracts (Meyer et al., 1982; Carballo et al., 2002).

The cytotoxicity of $A$. natalensis aerial parts extract was predicted by both assays; but it exhibited higher toxicity to mammalian cells than to brine shrimp larvae. The cytotoxic activity of $A$. natalensis $\left(\mathrm{CC}_{50}=18.57 \pm 1.04 \mu \mathrm{g} / \mathrm{mL}\right)$ on LLCMK2 cells was comparable to that of the standard cytotoxic drug used in this study (Imatinib, Gleevec) which had $\mathrm{CC}_{50}$ of 18.61 $\mu \mathrm{g} / \mathrm{mL}$. A previous study revealed that an infusion and paste prepared from leaves of A. natalensis are used topically in South Africa to treat skin diseases (Mabona et al., 2013), but information regarding its toxicity was limited. Information from the traditional healers who reported these plants indicated that the decoctions of A. natalensis leaves and A. toxicaria leaves and stem bark are used orally for malaria associated with high fever ("Malaria kali"). They, however, emphasized that the decoction of A. natalensis should be consumed in small quantity because if taken in large quantities it causes stomach pain. These results may support the safety concern raised by traditional healers regarding oral administration of extracts from this plant.

Antiaris toxicaria is a known poisonous plant used in arrow poisoning associated with the presence of a number of cardiac glycosides which are inhibitors of $\mathrm{Na}^{+} / \mathrm{K}^{+}$-ATPase pump (Kopp et al., 1992; Shi et al., 2010). In addition, the cardiac glycosides and coumarins isolated from A. toxicaria were reported to have cytotoxic activity on various cancer cell lines (Dai et al., 2009; Liu et al., 2013; Shi et al., 2014). In this study we found that ethanolic extracts of the leaves and stem bark of $A$. toxicaria were very toxic to non-cancer cells (LLC-MK2). However, these results do not support the questionnaire-based toxicity information collected from traditional healers. 
Table 1: Cytotoxic activity of crude extracts on LLC-MK2 cells $\left(\mathrm{CC}_{50} \pm \mathrm{SD}\right.$ in $\left.\mu \mathrm{g} / \mathrm{mL}\right)$.

\begin{tabular}{|c|c|c|c|c|}
\hline Plant family & Plant species & Vernacular name & $\begin{array}{l}\text { Plant } \\
\text { part }\end{array}$ & $\frac{\mathbf{C C}_{\mathbf{5 0}} \pm \mathbf{S D}(\boldsymbol{\mu g} / \mathbf{m L})}{80 \% \text { EtOH crude extract }}$ \\
\hline Acanthaceae & Acanthus pubescens (Oliv.) Vatke & Amatoju & $\mathrm{R}$ & $>200$ \\
\hline \multirow{4}{*}{ Apocynaceae } & Funtumia africana (Benth) Staff & Mwezamaino/omwelamaino & SB & $>200$ \\
\hline & Funtumia africana (Benth) Staff & Mwezamaino/omwelamaino & $\mathrm{L}$ & $>200$ \\
\hline & Holarrhena pubescens (Huch-Ham) & Nalupande & $\mathrm{R}$ & $>200$ \\
\hline & Holarrhena pubescens (Huch-Ham) & Nalupande & $\mathrm{R}$ & $>200^{\mathrm{b}}$ \\
\hline Burseraceae & Canarium schweinfurthii Engl. & Omubafu wa kike/muubani wa kike & SB & $>200$ \\
\hline Celastraceae & Salacia lovetii N. Halle \& B. Mathew & Omzindabikaka & $\mathrm{L}$ & $>200$ \\
\hline \multirow{4}{*}{ Compositae } & Aspilia mosambecensis (Oliv.) Wild & Eshurwa rusharila/Esisa & AP & $>200$ \\
\hline & Aspilia natalensis (Sond) Wild & Kanyamoisa & AP & $18.57 \pm 1.04$ \\
\hline & Guizotia scabra (Vis.) Chiov & Echihongosheija & WP & $>200$ \\
\hline & Vernonia glabra (Steetz) Vatke & Msangusangu & $\mathrm{L}$ & $100.75 \pm 16.69$ \\
\hline Convolvulaceae & Ipomoea rubens choisy & Kataba & $\mathrm{L}$ & $>200$ \\
\hline \multirow{3}{*}{ Euphorbiaceae } & Bridelia micrantha (Hochst.) Bail & Omushamako & SB & $156.80 \pm 0.44$ \\
\hline & Phyllanthus nummulariifolius Poir & Karungi & WP & $>200$ \\
\hline & Phyllanthus nummulariifolius Poir & Karungi & WP & $>200^{\mathrm{a}}$ \\
\hline \multirow{10}{*}{ Fabaceae } & Cassia singueana & Mlewelewe & $\mathrm{R}$ & $>200^{b}$ \\
\hline & Cassia singueana & Mlewelewe & $\mathrm{R}$ & $>200$ \\
\hline & Dalbergia malangensis E.P. Sousa & Omugorora & $\mathrm{L}$ & $107.29 \pm 11.04$ \\
\hline & Dalbergia malangensis E.P. Sousa & Omugorora & $\mathrm{S}$ & $>200$ \\
\hline & Desmodium salicifolium (Poir) DC & Batengeliange/Omukongoranwa & AP & $>200$ \\
\hline & Erythrina sacleuxii Hua & Mlindimila/mnungunungu & SB & $>200$ \\
\hline & Erythrina schliebenii Harms & Mlindimila & SB & $>200$ \\
\hline & Erythrina schliebenii Harms & Mlindimila & SB & $>200^{\mathrm{a}}$ \\
\hline & Erythrina schliebenii Harms & Mlindimila & $\mathrm{R}$ & $>200$ \\
\hline & Macrotyloma axillare (E. Mey) Verdc & Akaihabukuru & $\mathrm{AP}$ & $>200$ \\
\hline \multirow{3}{*}{ Labiatae } & Leonotis nepaetifolia (L.) R. Br & Ekitatelante & FL & $130.04 \pm 0.23$ \\
\hline & Leonotis nepaetifolia (L.) R. Br & Ekitatelante & $\mathrm{L}$ & $137.80 \pm 2.29$ \\
\hline & Leonotis nepaetifolia (L.) R. Br & Ekitatelante & $\mathrm{AP}$ & $124.13 \pm 11.86$ \\
\hline Logamiaceae & Anthocleista grandiflora Gilg & Omubagaigana/mbagaigana & SB & $>200$ \\
\hline \multirow{4}{*}{ Melastomataceae } & Dissotis brazzae Cogn & Bulitulo & AP & $134.47 \pm 2.7$ \\
\hline & Dissotis melleri Hook. f. & Ekituntun/Etuntun & AP & $83.33 \pm 3.31$ \\
\hline & Dissotis rotundifolia $(\mathrm{Sm})$ Triana & Obwehehe/Obwee & AP & $125.90 \pm 1.86$ \\
\hline & Melastomatrum capitatum (Vahl) A.\& R. Fern) & Katuntun/akatuntun & AP & $>200$ \\
\hline Melianthaceae & Bersama abyssinica & Omujalya & SB & $>200$ \\
\hline \multirow{2}{*}{ Moraceae } & Antiaris toxicaria (Pers) Lesch & Omujuju & SB & $1.44 \pm 0.48$ \\
\hline & Antiaris toxicaria (Pers) Lesch & Omujuju & $\mathrm{L}$ & $12.51 \pm 0.65$ \\
\hline \multirow{3}{*}{ Myristicaceae } & Pycnanthus angolensis (Welw.) Warb & Omunonoba & $\mathrm{F}$ & $136.32 \pm 3.09$ \\
\hline & Pycnanthus angolensis (Welw.) Warb & Omunonoba & SB & $>200$ \\
\hline & Pycnanthus angolensis (Welw.) Warb & Omunonoba & $\mathrm{L}$ & $>200$ \\
\hline Myrsinaceae & Maesa lanceolata Forsk & Omuzilanyama/omuhanga & $\mathrm{L}$ & $141.86 \pm 2.02$ \\
\hline Myrtaceae & Syzygium cordatum Krause & Omugege & SB & $>200$ \\
\hline Rosaceae & Eriobotrya japonica (Thunb.) Lindl & Musharazi/Omusharazi & $\mathrm{L}$ & $>200$ \\
\hline \multirow{5}{*}{ Rubiaceae } & Pentas bussei (K. Krause) & Rusharila kibira & AP & $>200$ \\
\hline & Hallea rubrostipulata (K. Schum) J.F.Leny & Mchunguchungu & $\mathrm{R}$ & $141.69 \pm 0.61$ \\
\hline & Hallea rubrostipulata (K. Schum) J.F.Leny & Mchunguchungu & SB & $>200$ \\
\hline & Oxyanthus speciosus DC & Omwanikibira & $\mathrm{L}$ & $>200$ \\
\hline & Rhytignia obscura Robyns & Omulokola/lulokola & $\mathrm{L}$ & $>200$ \\
\hline Rutaceae & Teclea amaniensis & - & $\mathrm{R}$ & $>200$ \\
\hline \multicolumn{3}{|c|}{ Standard drug: Gleevec (Imatinib) } & & $18.61 \pm 1.30$ \\
\hline
\end{tabular}

During our ethnobotanical survey, traditional healers reported that decoctions of leaves and stem bark were non-toxic when taken orally for treatment of malaria. This information from the reporting traditional healers is supported by animal studies. Kang et al., (2008) reported that aqueous and ethanolic leaf extracts of A. toxicaria were not toxic to mice even at high doses when given orally. But toxicity was observed when these extracts were administered by intra-peritoneal route. This may suggest that the bioavailability of the cardiac glycosides present in leaves and stem bark is low when given orally compared to when given through other routes. Apart from the toxicity evaluation reported in this study, the plant extracts reported in this study were previously evaluated for in vitro antimalarial activity against $P$. falciparum Dd2 strains. At a single concentration of $100 \mu \mathrm{g} / \mathrm{mL}$, ethanolic extracts from A. toxicaria stem bark, M. lanceolata leaves, A. natalensis and D. salicifolium aerial parts inhibited the growth of malaria parasites in vitro (Nondo et al., 2015). Since the LLCMK2 cells are normal mammalian cells, toxicity against these cells most likely predicts lack of selectivity and thus it will be toxic to mammalian cells, and therefore the traditional healers and patients should be informed on the risk of toxicity that might arise following use of extracts from these plants. 
Table 2: Brine shrimp toxicity results.

\begin{tabular}{|c|c|c|c|}
\hline Plant species & Part & $\mathrm{LC}_{50}(\mu \mathrm{g} / \mathrm{mL})$ & $95 \%$ CI $(\mu \mathrm{g} / \mathrm{mL})$ \\
\hline Acanthus pubescens (Oliv.) Vatke & $\mathrm{R}$ & 140.94 & $113.20-175.47$ \\
\hline Athocleista grandiflora Gilg & SB & $>1,000$ & \\
\hline Antiaris toxicaria (Pers) Lesch & $\mathrm{L}$ & 154.24 & $112.18-212.08$ \\
\hline Antiaris toxicaria (Pers) Lesch & SB & $>1,000$ & \\
\hline Aspilia mosambecensis (Oliv.) Wild & AP & 122.17 & $93.98-158.82$ \\
\hline Aspilia natalensis (Sond) & AP & 34.93 & $25.68-47.50$ \\
\hline Bersama abyssinica & SB & 729.14 & $433.75-1,225.68$ \\
\hline Bersama abyssinica & $\mathrm{R}$ & 184.35 & $126.88-267.86$ \\
\hline Bridelia micrantha (Hochst.) Bail & SB & $>1,000$ & \\
\hline Canarium schweinfurthii Engl. & SB & 273.51 & $203.66-367.32$ \\
\hline Cassia singueana & $\mathrm{R}$ & $>1,000$ & \\
\hline Cassia singueana & $\mathrm{R}^{\mathrm{b}}$ & 332.36 & $241.19-458.0$ \\
\hline Dalbergia malangensis E.P. Sousa & $\mathrm{L}$ & 16.47 & $10.78-25.17$ \\
\hline Dalbergia malangensis E.P. Sousa & Stem & 47.59 & $39.89-56.77$ \\
\hline Desmodium salicifolium (Poir) DC & AP & 36.87 & $28.96-46.94$ \\
\hline Dissotis brazzae Cogn & AP & 244.39 & $187.69-318.17$ \\
\hline Dissotis melleri Hook. f. & AP & 116.75 & $89.26-152.71$ \\
\hline Dissotis rotundifolia $(\mathrm{Sm})$ Triana & AP & $>1,000$ & \\
\hline Eriobotrya japonica (Thunb.) Lindl & $\mathrm{L}$ & $>1,000$ & \\
\hline Erythrina schliebenii Harms & SB & 729.14 & $433.75-1,225.68$ \\
\hline Erythrina schliebenii Harms & $\mathrm{R}$ & 93.26 & $74.97-116.02$ \\
\hline Funtumia africana (Benth) Staff & SB & 223.06 & $175.64-283.29$ \\
\hline Funtumia africana (Benth) Staff & $\mathrm{L}$ & 348.56 & $223.29-544.10$ \\
\hline Guizotia scabra (Vis.) Chiov & WP & 60.14 & $43.49-83.17$ \\
\hline Hallea rubrostipulata (K. Schum) J.F.Leny & SB & 125.45 & $99.01-158.95$ \\
\hline Hallea rubrostipulata (K. Schum) J.F.Leny & $\mathrm{R}$ & $>1,000$ & \\
\hline Holarrhena pubescens (Huch-Ham) & $\mathrm{R}^{\mathrm{a}}$ & 291.58 & $204.76-415.21$ \\
\hline Holarrhena pubescens (Huch-Ham) & $\mathrm{R}$ & 63.16 & $54.77-72.82$ \\
\hline Holarrhena pubescens (Huch-Ham) & $\mathrm{R}^{\mathrm{b}}$ & 135.24 & $111.40-164.19$ \\
\hline Ipomoea rubens choisy & AP & 97.01 & $73.05-128.83$ \\
\hline Leonotis nepaetifolia (L.) R. Br & AP & 128.74 & $90.92-182.30$ \\
\hline Leonotis nepaetifolia (L.) R. Br & FL & 91.75 & $68.62-122.67$ \\
\hline Macrotyloma axillare (E. Mey) Verdc & AP & 123.91 & $89.60-171.37$ \\
\hline Maesa lanceolata Forsk & $\mathrm{L}$ & 1.55 & $0.59-4.08$ \\
\hline Melastomatrum capitatum (Vahl) A.\& R. Fern) & AP & 390.17 & $267.79-568.48$ \\
\hline Oxyanthus speciosus DC & $\mathrm{L}$ & 229.48 & $152.28-345.83$ \\
\hline Pentas bussei (K. Krause) & AP & 729.14 & $433.75-1,225.68$ \\
\hline Phyllanthus nummulariifolius Poir & WP & 86.14 & $67.83-109.40$ \\
\hline Phyllanthus nummulariifolius Poir & $\mathrm{WP}^{\mathrm{a}}$ & 87.39 & $68.02-110.03$ \\
\hline Pycnanthus angolensis (Welw.) Warb & $\mathrm{F}$ & 81.01 & $52.74-124.43$ \\
\hline Pycnanthus angolensis (Welw.) Warb & $\mathrm{L}$ & 78.55 & $68.19-90.49$ \\
\hline Pycnanthus angolensis (Welw.) Warb & SB & 93.58 & $74.98-116.79$ \\
\hline Rhytignia obscura Robyns & $\mathrm{L}$ & 489.33 & $296.20-608.37$ \\
\hline Syzygium cordatum Krause & SB & 99.93 & $80.33-124.31$ \\
\hline Vernonia glabra (Steetz) Vatke & $\mathrm{L}$ & $>1,000$ & \\
\hline
\end{tabular}

Vernonia glabra (Steetz) Vatke

$>1,000$

$\mathrm{S}=$ stem, $\mathrm{SB}=$ stem bark, $\mathrm{L}=$ leaves, $\mathrm{AP}=$ aerial parts $($ stem + leaves $), \mathrm{F}=$ fruits, $\mathrm{FL}=$ flowers, $\mathrm{WP}=$ whole plant.

\section{CONCLUSION}

Most of the antimalarial medicinal plants tested were non-toxic, and hence support the traditional healers' claims who believe that the herbal medicines they use are safe. However, further studies using different toxicity models are suggested to confirm their claims. Only the extracts of A. natalensis and A. toxicaria were categorized as toxic to mammalian cells. The evidence of $A$. natalensis toxicity obtained in this study supports the cautionary note that was given by the collaborating traditional healers.

\section{ACKNOWLEDGEMENTS}

The authors are very grateful to the Swedish International Development Cooperation Agency (Sida) for financial support.
The authors also wish to acknowledge traditional healers (Mr. Mohamed Ngalanga, Mr. Didas Ngemera, Mr. Dominic Mushwahili, Mr. Buchadi Tibikunda and Mr. Papianus Rwechungura) and the Botanist (Mr. Haji.O. Selemani) for their assistance in collecting plants used in this study. Extraction of the plant extracts and brine shrimp toxicity assay were done at the Institute of Traditional Medicine in Tanzania; whereas toxicity study on LLC-MK2 cells was done at the Research Foundation in Tropical Diseases and Environment, and at the University of Buea in Cameroon.

\section{REFERENCES}

Abdualmjid RJ, Sergi C. Hepatotoxic Botanicals: An Evidencebased Systematic Review. J Pharm Pharmaceut Sci, 2013; 16(3): 376-404.

Apers S, Baronikova S, Sindambiwe J. B, Witvrouw M, De Clercq E, Vanden Berghe D, Van Marck E, Vlietinck A, Pieters L. Antiviral, haemolytic and molluscicidal activities of triterpenoid saponins 
from Maesa lanceolata: establishment of structure-activity relationships. Planta Med, 2001; 67(6):528-32.

Butler MS. The role of Natural Product Chemitry in Drug Discovery. J Nat Prod, 2004; 67: 2141-2153.

Carballo JL, Hernández-Inda ZL, Pérez P, García-Grávalos MD. A comparison between two brine shrimp assays to detect in vitro cytotoxicity in marine natural products. BMC Biotechnology, 2002; 2:17.

Chalut et al. Drug therapy and hazardous substances committee: Toxicological risks of herbal remedies. Paediatr Child Health, 1999; 4(8): $536-538$.

Dai H, Gan Y, Que D, Wu J, Wen Z, Mei W. A new cytotoxic 19-Nor-cardenolide from the latex of Antiaris toxicaria. Molecules, 2009; 14:3694-3699.

Debelle FD, Vanherwghem J, Nortier JL. Aristolochic acid nephropathy: A worldwide problem. Kidney International, 2008; 74:158169.

Fadeyi SA, Fadeyi OO, Adejumos AA, Okoro C, Myles EL. In vitro anticancer screening of 24 locally used Nigerian medicinal plants. BMC Compl and Altern Med, 2013; 13:79.

Fidock DA, Rosenthal P J, Croft SL, Brun R, Nwaka S. Antimalarial Drug Discovery: Efficacy Models for Compound Screening. Nat Rev Drug Discov, 2004; 3:509-520.

Gessler MC, Msuya DE, Nkunya MHH, Mwasumbi LB, Schar A, Heinrich M., Tanner M. Traditional healers in Tanzania: the treatment of malaria with plant remedies. J Ethnopharmacol, 1995; 48:131-144.

IARC. 2012. IARC monographs on the evaluation of carcinogenic risks to humans: A review of human carcinogens, volume 100A. IARC, Lyon, France 2012. [ONLINE] Available at: monographs.iarc.fr/ENG/Monographs/vol100A/mono100A.pdf.

Kang S, Ren S, Ouyang L, Qiu M, Liu M. Study on the Acute Toxicity of Leaves of Antiaris toxicaria Lesch. Lishizhen Medicine and Materia Medica Research; 2008-9.

Kinung'hi SM, Mashauri F, Mwanga JR, Nnko SE, Kaatano GM, Malima R, Mboera LE. Knowledge, attitudes and practices about malaria among communities: comparing epidemic and non-epidemic prone communities of Muleba district, North-western Tanzania. BMC Public Health, 2010; 10:395.

Kopp B, Bauer WP, Schmüch AB. Analysis of some Malaysian dart poison. J Ethnopharmacol, 1992; 36(1):57-62.

Liu Q, Tang J, Hu M, Liu J, Chen H, Gao H, Wang G, Li S, Hao X, Zhang X, Yao X. Antiproliferative cardiac glycosides from latex of Antiaris toxicaria. J Nat Prod, 2013; 76:1771-1780.

Mabona U, Van Vuuren SF. Southern African medicinal plants used to treat skin diseases. S Afr J Bot, 2013; 87:175-193.

Mahunnah RL. Traditional plant medicines used by Hayas of North-western Tanzania. J Econ and Taxon Bot, 1987; 10 (2): 371-379.

Mahunnah RLA, Uiso FC, Kayombo EJ. 2012. Documentation of Traditioanal Medicine in Tanzania: A Traditioanal Medicine Resource Book. Dar es Salaam, Tanzania: Dar es Salaam University Press.

Meyer BN, Ferrign RN, Putnam JE, Jacobson LB, Nicholas DE, McLaughlin JL. Brine Shrimp: A convenient general bioassay for active plant constituents. Planta Medica, 1982; 45:31-34.

Moshi MJ, Innocent E, Magadula JJ, Otieno DF, Weisheit A, Mbabazi PK, Nondo RSO. Brine Shrimp of Some Plants used as Traditional Medicine in Kagera Region, Northwest Tanzania. TJHR, 2010; 12:63-67.
Moshi MJ, Otieno DF, Mbabazi PK, Weisheit A. The ethnomedicine of the Haya people of Bugabo ward, Kagera Region, north western Tanzania. J Ethnobiol and Ethnomed, 2009; 5:24.

NIAID. 2007. Understanding Malaria: fighting an Ancient Scourge. NIH Publication 2007, No.07-7139. [ONLINE] Available at http://www.niaid.nih.gov/topics/malaria/documents/malaria.pdf. [Accessed 20 August 2011].

Niles AL, Moravec RA, Riss TL. In vitro viability and cytotoxicity testing and same-well multi-parametric combinations for high throughput screening. Curr Chem Genomics, 2009; 3:33-41.

Niles AL, Moravec RA, Riss TL. Update on in vitro cytotoxicity assays for drug development. Expert Opin Drug Discov, 2008; 3(6):655-69.

Nondo RSO, Mbwambo ZH, Kidukuli AW, innocent EM, Miale MJ, Erasto P, moshi MJ. Larvicidal, antimicrobial and brine shrimp activities of extracts from Cissampelos mucronata and Tephrosia villosa from Coast region, Tanzania. BMC Comp Alt Med, 2011; 11:33.

Nondo RSO, Zofou D, Moshi MJ, Erasto P, Wanji S, Ngemenya MN, Titanji VPK, Kidukuli AW and Masimba PJ. Ethnobotanical survey and in vitro antiplasmodial activity of medicinal plants used to treat malaria in Kagera and Lindi regions, Tanzania. J Med Plants Res, 2015; 9(6): 179 -192.

Petrovska BB. Historical review of medicinal plants' usage. Pharmacog Rev, 2012; 6(11): 1-5.

Shi L, Kuo S, Sun H, Morris-Natschke SL, Lee K, Wu T. Cytotoxic cardiac glycosides and coumarins from Antiaris toxicaria. Bioorg Med Chem, 2014; 22(6):1889-1898.

Shi L, Liao Y, Su M, Lee A, Kuo P, Damu AG, Kuo S, Sun H, Lee K, Wu T. Cardiac glycosides from Antiaris toxicaria with potent cardiotonic activity. J N Prod, 2010; 73(7):1214-1222.

Sindambiwe JB, Calomme M, Geerts S, Pieters L, Vlietinck AJ, Vanden Berghe DA. Evaluation of biological activities of triterpenoid saponines from Maesa lanceolata. J Nat Prod, 1998; 61(5):585-90.

Van der Bijl P (Jr.), Van der Bijl P (Sen.). Cardiotoxicity of plants in South Africa. Cardiovas J Afr, 2012; 23(9): 476-477.

Wells TN. Natural products as starting points for future antimalarial therapies : going back to our roots?. Malaria Journal, 2011; 10 (Suppl 1): S3.

Westendorf J. 1999. Plant toxins. In: Marquardt H, Schäfer SG, Mc Clellan RO, Welsch F, ed. Toxicology. Califonia: Academic Press 959-1007.

WHO. 2012. WHO Global Malaria Programme. World Malaria Report 2012. Geneva; Swirtzerland.

WHO. 2002. WHO Traditional Medicine Strategy 2002-2005. WHO/EDM/TRM/2002.1. Geneva.

\section{How to cite this article:}

Nondo R.S.O., Moshi M. J., Erasto P., Zofou D., Njouendou A. J., Wanji S., Ngemenya M.N., Kidukuli A.W., Masimba P.J., Titanji V.P.K. Evaluation of the cytotoxic activity of extracts from medicinal plants used for the treatment of malaria in Kagera and Lindi regions, Tanzania. J App Pharm Sci, 2015; 5 (04): 007-012. 